\title{
Antidumping: The Third Rail of Trade Policy
}

\section{Citation}

Mankiw, N. Gregory, and Phillip Swagel. 2005. Antidumping: The Third Rail of Trade Policy. Foreign Affairs 84(4): 107-119

\section{Permanent link}

http://nrs.harvard.edu/urn-3:HUL.InstRepos:2961701

\section{Terms of Use}

This article was downloaded from Harvard University's DASH repository, and is made available under the terms and conditions applicable to Other Posted Material, as set forth at http:// nrs.harvard.edu/urn-3:HUL.InstRepos:dash.current.terms-of-use\#LAA

\section{Share Your Story}

The Harvard community has made this article openly available.

Please share how this access benefits you. Submit a story.

Accessibility 


\section{Antidumping: The Third Rail of Trade Policy}

\section{N. Gregory Mankiw and Pbillip L. Swagel}

NOT FAIR

IT DID NOT take long for the newest class of U.S. senators to pledge its allegiance to one of the few trade policies that politicians of both parties overwhelmingly support. In February, seven of nine newly elected senators publicly endorsed the Byrd Amendment, a provision that encourages American companies to file antidumping lawsuits by awarding the revenues collected from the resulting tariffs to the litigating companies. The ostensible purpose of antidumping law is to help ensure competition by punishing foreign firms that sell their products at "unfair" prices in U.S. markets. In practice, however, antidumping has strayed far from this purpose, becoming little more than an excuse for special interests to shield themselves from competition at the expense of both American consumers and other American companies.

Antidumping is the "third rail" of U.S. trade politics, with few politicians of either party willing to point out its broadly negative impact. Antidumping statutes are extremely complex, and few voters understand how they work and what effect they have. Advocates of antidumping measures claim that they guarantee that international trade is competitive and fair. And who, they ask, could be against

\footnotetext{
N. Gregory Mankiw is Professor of Economics at Harvard University and was Chair of the President's Council of Economic Advisers from May 2003 to February 2005. PHilli P L. SwAge L is Resident Scholar at the American Enterprise Institute and was Chief of Staff of the Council of Economic Advisers from July 2002 to February 2005.
} 


\section{N. Gregory Mankiw and Phillip L. Swagel}

fairness? But such rhetoric bears little relation to economic reality. Rather than promote fairness and competition, the American producers who petition for antidumping tariffs - a powerful and often unrecognized lobby - use them to thwart foreign competition. In essence, "antidumping" means little more than "antibargain." If a foreign firm sells its product in the U.S. market at too attractive a price, domestic firms can threaten it with an antidumping suit that will lead to hefty tariffs and higher prices.

What is especially perverse is that the impact of antidumping tariffs falls most harshly on two groups whose interests members of Congress should be working to protect: the least well-off of their constituents and the vast majority of American producers. All Americans pay higher prices for food and housing as a result of antidumping tariffs, but the burden is likely greatest on the poor, because these necessities make up a larger share of their spending. U.S. producers are affected because most items hit with antidumping tariffs are not finished goods but components that are used to make other items. Since 1989, for example, imported ball bearings have been subject to tariffs ranging above 50 percent. U.S. manufacturers of ball bearings surely benefit, but there are many more buyers of ball bearings in the United States than there are producers - and all of them end up paying significantly more than they should and than their foreign competitors do. Antidumping practice has also become a growing obstacle for U.S. exporters.

Firms that benefit from antidumping and their allies in Congress hotly contest any change that weakens antidumping law. Yet for all their claims that antidumping policy ensures that trade is fair, it is little more than an opaque way of protecting favored industries that have powerful lobbies - doing, in the process, significant damage to everyone else.

\section{GOING ASTRAY}

FREE TRADE benefits the world economy by pushing countries to specialize in the goods and services they produce most efficiently. Just as a shopper benefits from a sale, each nation benefits from paying less for products it buys on the world market. Antidumping law was created 


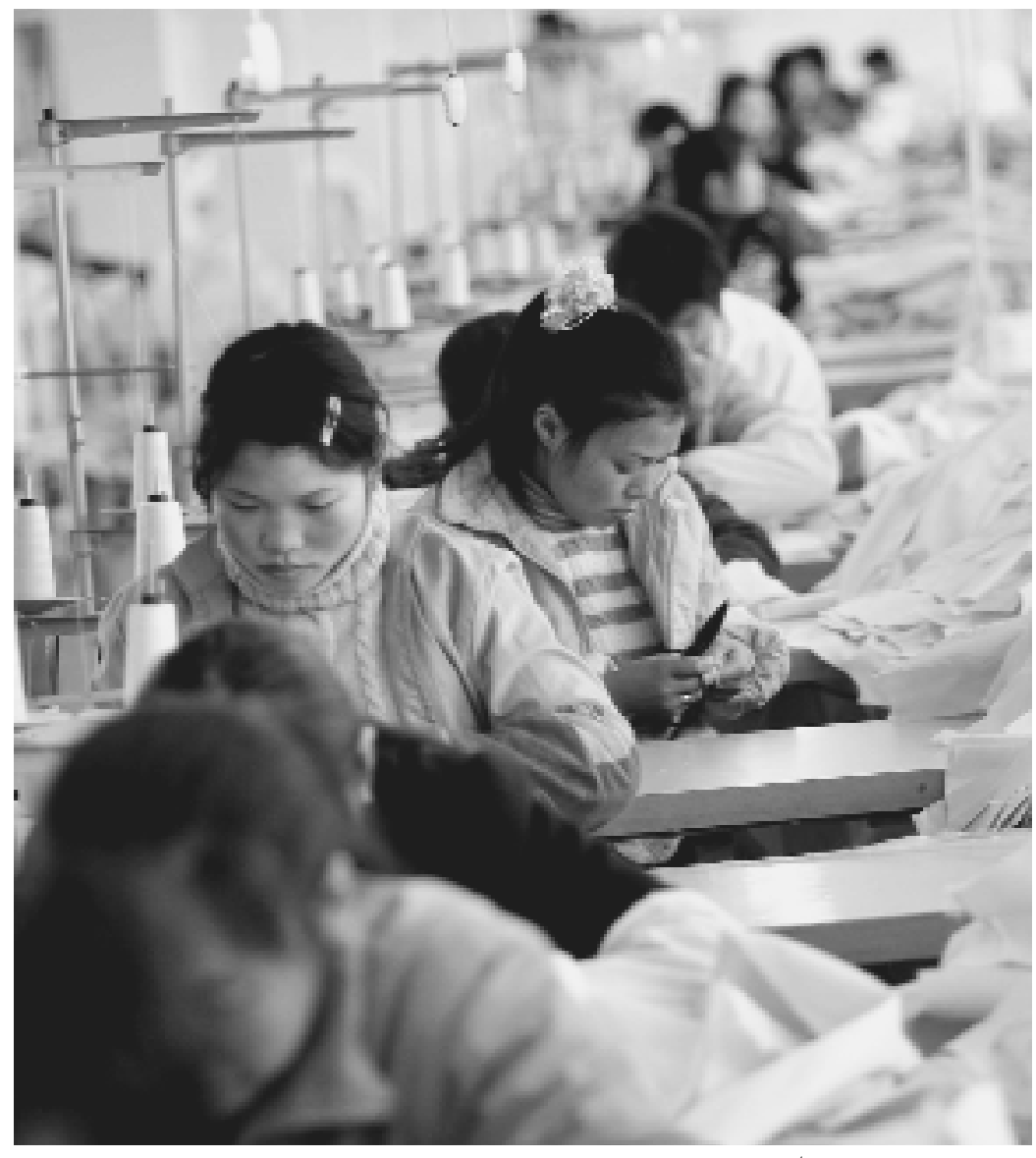

AP/WIDE WORLD PHOTOS

Free trade in action? Chinese textile workers, Jiaxing, March 8, 2004

to address an exception to this principle: when a foreign company uses temporary low prices to drive its competitors out of a market and then raises prices, a practice known as "predatory pricing." Antidumping statutes purport to defend against this by preventing the sale of foreign goods "at less than fair value."

But defending against "predatory pricing" and enforcing "fair value" as it has come to be understood are two very different things-a distinction that is crucial for understanding how U.S. trade law has gone so far astray. As soon as one tries to define what a "fair" price is, it quickly becomes apparent that the idea is elusive. In a competitive system of world trade, where resources are allocated by the invisible hand of the market and prices are untainted by either government intervention or the exercise of monopoly power, prices are determined by supply and demand, and the voluntary nature of commerce ensures 


\section{N. Gregory Mankiw and Phillip L. Swagel}

that trade benefits both parties. The debate over fair prices begins with deviations from this ideal: What if a government subsidizes a particular industry? What if a country has a single large producer that charges lower prices in more competitive markets and higher prices in less competitive ones?

Such deviations make prices seem less natural. But do they make commerce undesirable for either party? Not necessarily. If a country is a net exporter of a product, high prices are generally good; if a country is a net importer of a product, low prices are generally good, even if those prices are the result of practices that might be viewed as unfair. The notable exception to this rule is a situation in which, thanks to predatory pricing, lower prices today will reduce competition in the future. If, to use one of David Ricardo's examples, a wine supplier uses lower prices to drive competitors out of business and new firms are slow to enter the market, consumers lose out - the harm of the ensuing higher prices outweighs the initial benefits of low prices. On the other hand, if the price war lasts long enough or if the would-be predator is unable to raise prices in the end because of the entrance of new competitors, consumers are net winners. The possibility of new firms entering a market is thus a crucial constraint on anticompetitive behavior.

The precursor to modern antidumping law was the seminal Sherman Antitrust Act of 1890 . Antitrust laws are intended to protect consumers from predatory pricing and other forms of anticompetitive behavior by firms seeking to establish a monopoly. By the standards of antitrust, low prices are a problem not when they simply harm other competitors, but when they threaten to wipe out competition and thereby ultimately harm consumers. In practice, this situation is rare. Firms usually cut prices as part of the competitive process, not in an attempt to thwart it. Thus, to prove that a firm is seeking a monopoly, it is necessary to show it has taken actions that do not make business sense apart from their stifling effects on competition.

Current U.S. antidumping practice is based on the Antidumping Act of 1921, which followed the example of a 1904 Canadian law that allowed the government to block imports sold at "less than fair value." (The original target of the Canadian measure was U.S. Steel; as a result of it, the company was obliged to raise the prices of the materials 


\section{Antidumping: The Third Rail of Trade Policy}

it supplied to build Canadian railroads in order to avoid a tariff.) The Antidumping Act of 1921 adopted this notion of "fair value," straying from the idea that antidumping measures were meant strictly to protect consumers and markets from anticompetitive practices. The act grants protection from imports as long as a company can prove that a foreign firm's actions are designed to injure or threaten to injure an American industry. If these conditions are met, the government imposes a tariff worth the "dumping margin"-the difference between the price of the imported product and its "fair value," defined as a price above the cost of production and at least as high as the price charged in the foreign firm's home market.

From an economic standpoint, selling at prices below "fair value" can be considered normal business practice. If competition in the U.S. market is fiercer than competition in a foreign market, for example, a foreign firm might be able to maximize profits by selling its products in the United States at lower prices than in its home country. Rather than the result of predatory practices by foreign firms, lower prices are often the result of healthy competition; outlawing them denies American consumers the benefits of such competition. Consider as well that within the United States firms are allowed to charge different prices to different consumers. Movie theaters, for example, charge an adult more for a ticket than they charge a child, even though they each take one seat. Likewise, pharmaceutical firms can charge more for drugs in high-income countries than they do in low-income countries.

Predatory pricing is a very different matter, since it harms not only domestic competitors but, in the long run, American consumers as well. Unfortunately, U.S. antidumping law has come to ignore the distinction between the two different kinds of low prices. Since the Antidumping Act of 1921, there has been no requirement to show that dumping is predatory; one need only prove that prices are either below cost or below the price charged for a similar item in a firm's home market.

An unintended consequence of this evolution is that modern antidumping practice actually facilitates the kind of unfair and anticompetitive behavior it was intended to prevent. When a group of firms in a market tries to act in concert to keep prices high, one check 


\section{N. Gregory Mankiw and Phillip L. Swagel}

on their collusive behavior is the possibility that a competitor will undercut them. Allowing domestic firms to threaten foreign competitors with antidumping action makes it easier for them to keep prices high. And not only do antidumping tariffs themselves restrict trade, but investigations into dumping also have a restrictive effect. Research by Bruce Blonigen and Thomas Prusa has shown that the mere threat of antidumping action is a valuable tool for a domestic firm trying to impede competition from abroad.

\section{KEEPING PRICES HIGH}

An investigation of alleged dumping by a foreign firm typically proceeds along two concurrent paths. While the Commerce Department's Import Administration investigates whether the imported product has been sold in the United States at less than fair value, the U.S. International Trade Commission (ITC) investigates whether a domestic industry has been injured or threatened with injury by the allegedly dumped imports. If both dumping and injury are established, a tariff is levied equal to the dumping margin.

These tariffs have a substantial impact on trade, and that impact has grown considerably in recent years. Antidumping tariffs are often substantially larger than other kinds of protection. One study found that antidumping duties are on average 10 to 20 times higher than normal tariffs. And once imposed, antidumping tariffs are not easily removed. Although they can be lifted after a "sunset review" that occurs every five years, they carry no fixed time limit and therefore tend to last for considerable periods. The Department of Commerce lifted tariffs in only two of the 314 cases it reviewed between 1998 and 2000 . Recently, the increased use of discretion by Department of Commerce staff in calculating dumping margins has led to an increase in antidumping tariffs - an increase that has nearly reversed reductions in dumping margins resulting from rule changes agreed to by Washington in 1995 during the Uruguay Round of international trade talks.

These antidumping measures do considerable harm to both American consumers and American business. Research by Michael Gallaway, Bruce Blonigen, and Joseph Flynn found that in 1993 antidumping and antisubsidy tariffs (the latter are meant to counteract 


\section{Antidumping: The Third Rail of Trade Policy}

the effects of foreign subsidies) had economic costs of $\$ 4$ billion (\$5 billion in today's prices), with most of the harm caused by antidumping tariffs, which outnumber antisubsidy measures by more than three to one. Since then, the economic cost of antidumping laws has likely increased. Although average antidumping tariffs have fallen somewhat since 1993, from 50.6 percent between 1991 and 1993 to 41.9 percent between 1997 and 1999, the value of imports affected has increased substantially. Some $\$ 14$ billion worth of imports were covered by antidumping tariffs approved between 1994 and 2003, up from $\$ 8.34$ billion between 1984 and 1993 .

Most antidumping tariffs are levied on components used in the production of other goods rather than on items sold directly to consumers. As a result, "downstream" firms using the affected items as production inputs face higher costs. U.S. automakers, for example, must pay more for steel, making their cars less competitive against imports. This is the case even if they use no imported steel, since domestic steel firms can raise prices behind the antidumping barrier. In some cases, the impact is large enough to cause American firms to shift jobs out of the United States.

Each job saved by steel tariffs came at the cost of three jobs in steel-using industries. Antidumping tariffs of 62.7 percent imposed in 1991 on flat-panel displays prompted U.S. companies to shift production of notebook computers from the United States to Asia, since imports of whole computers did not face the punitive tariff. Toshiba closed a California production facility to open one in Japan, and Apple Computer set up a facility in Ireland rather than stick to its original plan of assembling laptops in Colorado.

The U.S. steel industry has long been the leading user of antidumping procedures: nearly half of antidumping tariffs imposed since 1970 have been on steel imports, and 158 of the 294 antidumping orders in force as of April 2005 were on steel products. Such tariffs continue despite strong performance by U.S. steel firms and a 45 percent jump in steel prices between December 2003 and March 2005. These higher steel prices help steel producers, but they hurt the much larger number of firms and workers that use steel. Whereas steel producers employed just under 160,000 workers in early 2005 , more than 1.5 million 


\section{N. Gregory Mankiw and Phillip L. Swagel}

employees worked at firms that manufacture metal products, more than 1.1 million at firms that manufacture machinery, and nearly 1.8 million at firms that produce transportation equipment such as cars and parts. One recent study found that each job saved by steel tariffs came at the cost of three jobs in steel-using industries and caused economic distortions equal to some $\$ 450$, 000 .

Foreign firms also use U.S. antidumping laws to inhibit competition. In late 2003, imports of Chinese television sets 21 inches and larger were hit with antidumping tariffs of up to 78 percent ( 5 to 26 percent for most firms) as a result of a case filed by U.S. companies that assemble televisions on behalf of Japanese and Korean television manufacturers. These tariffs exclude newer digital models, affecting instead the lowerend televisions sold mainly in discount stores.

The total effect of antidumping laws probably surpasses these visible costs, because the mere existence of such laws causes firms to change their behavior in ways that are not easily measured. Just knowing that lower prices might trigger antidumping tariffs can lead foreign firms to charge higher prices than they might otherwise in order to reduce the risk of becoming entangled in trade lawsuits. In some cases, antidumping suits are resolved by "suspension agreements," under which foreign firms agree to minimum prices for goods they export to the United States. It is no small irony that the Department of Commerce sets prices in this fashion for steel plates imported into the United States from the former Soviet Union.

Antidumping tariffs change over time in ways that cause additional economic harm. After the dumping margin is calculated, foreign firms are allowed to ask for the duties to be adjusted through periodic administrative reviews that take into account any recent price increases. In theory, they can even request that the antidumping tariffs be removed after showing that import prices have risen by the same amount as the tariff. If they win, consumers face the same bottom-line price, but the U.S. Treasury no longer collects the tariff revenue. Instead, it goes to the foreign firm in the guise of a higher price. In reality, antidumping tariffs are computed so as to make it impossible for foreign firms to raise prices by an amount that precisely offsets the tariffs. Nonetheless, research has found that about half of the economic harm caused by antidumping laws stems from the impact of foreign firms raising prices 


\section{Antidumping: The Third Rail of Trade Policy}

after tariffs are imposed, thereby depriving American consumers of lower prices and the U.S. government of the associated tariff revenues. (The other half of the harm results from market distortions, as users of the goods affected by tariffs change their behavior in response to the higher prices.)

\section{ABSURDITIES}

THE HARM to U.S. consumers and producers from antidumping law goes well beyond higher prices. U.S. exporters are increasingly hampered by the use of antidumping actions in the rest of the world. Moreover, antidumping policies have become a point of contention in international trade negotiations, threatening to undermine the mission of the World Trade Organization (wTO) and the overall expansion of free trade.

Although the United States and the European Union initiate the largest number of antidumping suits, developing countries are now the heaviest users of antidumping measures per dollar of imports. Argentina, Brazil, India, and South Africa use antidumping laws 5 to 20 times more often than the United States does. Over the last decade, only Chinese and South Korean firms have been accused of dumping more than U.S. firms.

Not coincidentally, American exporters face dumping charges in many of the markets where they have been most successful. Mexico has initiated six antidumping investigations against U.S. exports in the last year, often targeting agricultural products, including ham, beef, rice, and apples. U.S. exports to China have been growing at roughly 30 percent per year, and the number of antidumping cases filed against U.S. firms there has grown even faster. Some $\$ 286$ million in U.S. exports were subject to Chinese antidumping actions in 2003, up 65 percent from 2002. The vast majority of these cases involve chemical products, with supposed dumping margins ranging from 7 to 112 percent. Research by Thomas Prusa and Susan Skeath has found that the increase in antidumping allegations is motivated, at least in part, by a desire for retaliation against U.S. antidumping actions, not by a change in the trading practices of U.S. exporters.

Recent antidumping tariffs applied to U.S. chicken exports to South Africa illustrate the frequent absurdity of the proceedings. Chicken 


\section{N. Gregory Mankiw and Phillip L. Swagel}

eaters in the United States prefer white meat; chicken eaters in South Africa prefer dark meat. Since chickens come with both white and dark, this would seem to present an ideal opportunity for trade. In 1999, however, the South African Board of Tariffs and Trade (втт) initiated an antidumping case against U.S. chicken exporters for selling below fair value. The BTT approached the question of fair value by comparing the sales price of exports to the computed costs of production (a method that has become increasingly common in recent years). But how to determine the cost of producing dark chicken meat versus the cost of producing white chicken meat? Since a "scientific" approach to this question is impossible, the U.S. exporters offered one calculation of the cost of producing dark meat while the BTT used another. In the end, the вт judged that the two U.S. exporters involved were dumping dark meat by margins of 209 percent and 357 percent. As a result, U.S. exports of poultry to South Africa fell to a mere $\$ 307,000$ in 2001 , a decline of 80 percent from the previous year. These duties remain in force.

Antidumping has also become an increasingly frequent subject of WTo disputes, and the United States has fought vigorously to preserve its right to use antidumping policies. Although trade agreements offer general guidelines for acceptable antidumping practices, wTO members implement them very differently. One ongoing dispute concerns the U.S. practice of "zeroing," which allows officials to disregard instances in which foreign firms charge prices over fair value, thus offsetting supposed instances of undercharging. Consider, for example, a foreign firm that sells a product in its home and U.S. markets. Six months a year, the firm charges $\$ 10$ in its home market and $\$ 8$ in the United States; the other six months a year, it charges $\$ 8$ at home and $\$ 10$ in the United States. On average, the firm charges \$9 both overseas and in the United States. But under zeroing, a U.S. official can define this as dumping, with each sale in the first half of the year assigned a dumping margin of $\$ 2$ and each sale in the second assigned a dumping margin of zero (rather than $-\$ 2$ ). Instead of letting the overpricing offset the underpricing, which would mean no tariff, the average dumping margin — and the resulting tariff-is \$1. Europe's version of zeroing was recently found to be contrary to its WTO obligations. The U.S. government has asserted that its version differs from the Europeans' and is attempting to defend its practice before the wTo. The 


\section{Antidumping: The Third Rail of Trade Policy}

WTO is unlikely to accept Washington's defense, hinting at yet another defeat for the United States in the wTo dispute process.

Another dispute before the wTO involves the Byrd Amendment. The provision, first proposed as the Continued Dumping and Subsidy Offset Act, became law when it was attached to appropriations legislation in 2000. Even while signing the measure, President Bill Clinton noted that it was contrary to U.S. obligations at the WTO and called for its quick repeal.

U.S. antidumping law requires that a filing must have the support of a significant portion of the domestic industry in question, and the Byrd Amendment gives all firms in the industry a financial incentive to support a case by determining that a firm only receives a share of the collected tariffs if it backs the initial filing. It also gives petitioning industries a double serving of federal assistance: they benefit first from the increase in prices when antidumping tariffs are applied and then from a subsidy when the revenues are distributed. Through 2004, payments under the Byrd Amendment totaled more than $\$ 1$ billion, and the Congressional Budget Office estimates that such payments will exceed $\$ 5$ billion between 2005 and 2015 .

A wTo panel ruled against the Byrd Amendment in September 2002, allowing countries in the European Union and several other nations to apply retaliatory tariffs against U.S. exports. The decision was upheld on appeal in January 2003. The Bush administration has repeatedly called for the Byrd Amendment to be repealed, but Congress has so far failed to act. In the meantime, the retaliatory tariffs took effect in May.

\section{A BETTER WAY}

AdDRESSING THE excesses of antidumping policy could well play a critical role in the Doha Development Agenda talks now being conducted under the auspices of the wTO. Outright repeal of U.S. antidumping laws would certainly be the best policy for the United States' well-being, but it is politically infeasible. The Trade Act of 2002, which granted trade promotion authority to the president, requires that he provide Congress with at least 180 days advance notice before signing a trade agreement that affects U.S. antidumping law 


\section{N. Gregory Mankiw and Phillip L. Swagel}

or other trade remedies. A principal objective of the act was to "preserve the ability of the United States to enforce rigorously its trade laws," including antidumping and other laws regulating unfair trade.

A second-best compromise that recognizes these political constraints could still improve on current trade law. Antidumping has two objectives: to protect U.S. firms against predatory pricing and to give them time to adjust to new levels of competition. Today's policy is not well suited to either goal. Fortunately, there are better ways to meet both. To be sure, free trade remains the ideal, but the best should not become the enemy of the good in designing and implementing trade policy.

Concerns about predatory pricing could be met by revising antidumping law to address the antitrust concerns that inspired it. Government should be able to protect against those rare instances when a foreign firm does approach the U.S. market with the intent of establishing a monopoly. But it does not need current antidumping law to do so; this can be effectively achieved by giving the Department of Justice an enhanced role in antidumping proceedings and reducing the role of the Department of Commerce.

A better way to protect industries adjusting to increased competition would be through the increased use of "safeguard tariffs," a type of trade barrier that is explicitly temporary. Increased use of safeguards may fall short of the free-trade ideal, but they cost the U.S. economy far less than do antidumping tariffs. (When tariffs are in place for more than three years, the WTO allows countries whose exports are affected by the safeguards to levy retaliatory tariffs.) Like antidumping duties, safeguards can be put in place only if the ITC determines that specific imports are hurting a domestic industry. The legal hurdle for getting a safeguard, however, is higher: unlike antidumping tariffs, which can be levied when imports merely cause material injury, safeguards are permissible only when the ITC finds that no other factor is more important than imports in causing harm to a U.S. industry. In return for the higher standard of injury with safeguards, importcompeting firms in the United States do not have to show that the foreign firms took any particular actions. No consideration is given in safeguard determinations as to whether trade is fair or unfair.

The law governing safeguard tariffs also gives the president an opportunity to balance the needs of the import-competing community 


\section{Antidumping: The Third Rail of Trade Policy}

against the interests of the rest of the country. Although the ITC issues a recommendation, the president, according to the legislation, has the discretion to impose trade barriers as he sees fit, balancing "the shortand long-term economic and social costs" of the safeguard tariffs with "other factors related to the national economic interest of the United States." And in return for trade barriers, the domestic industry must put forward a plan for adjustment and show progress in making the adjustment - or face the prospect of having the safeguard tariffs removed by presidential action.

Proponents of antidumping measures frequently point to the hostile reception safeguard actions have received at the WTO. A series of WTO rulings has indeed made it difficult for the ITC to find that imports hurt an American industry at least as much as any other cause. A useful negotiating goal in the Doha negotiations would be to clarify the rules governing safeguards in the WTO so as to facilitate their temporary use. Meanwhile, Washington should amend the administrative procedures to remove zeroing, rather than wait for a WTO panel to force the issue. Such a move would reduce dumping margins and avert another U.S. defeat at the wTo. Each such loss is a blow to public and congressional support for an institution that is a powerful force for improving global economic conditions and promoting international cooperation.

In international trade negotiations, a government will typically offer as "concessions" actions that are economically desirable but politically difficult at home. In a sense, each party in a trade negotiation uses the need to make concessions to the other side as an excuse to undertake actions that, absent politics, it should be willing to make on its own. The U.S. economy has benefited enormously from the liberalization it has "conceded to" in decades of trade negotiations. Any move to limit the use of antidumping policy would certainly be cast as a major concession as well. It is a concession Washington should be eager to make. Such a change would offer great benefits to both American consumers and American producers and pave the way for a return to antidumping's original purpose: ensuring rather than restricting competition. 